\title{
REPRESENTASI INTERAKSI MANUSIA DALAM GENRE FOTOGRAFI "STORY" SITUS MEGALITIKUM GUNUNG PADANG
}

\author{
Winny Gunarti Widya Wardani ${ }^{1}$, Wulandari ${ }^{2}$, Rezha Destiadi $^{3}$ dan Syahid $^{4}$ \\ $123{ }^{4}$ Desain Komunikasi Visual, Fakultas Bahasa dan Seni, Universitas Indraprasta PGRI, Jakarta \\ ${ }^{1}$ winny.gunartiww@unindra.ac.id, ${ }^{2}$ wulandari@unindra.ac.id, ${ }^{3}$ rezha.destiadi @ unindra.ac.id, \\ dan ${ }^{4}$ syahid @unindra.ac.id
}

Masuk :10-04-2019, revisi: 09-09-2019, diterima untuk diterbitkan : 09-09-2019

\begin{abstract}
ABSTRAK
Situs Megalitikum Gunung Padang terletak di Desa Karyamukti, Kabupaten Cianjur. Situs yang berasal dari zaman prasejarah ini memiliki banyak serakan batu berpola dan tersusun dalam lima teras berundak. Situs ini bernilai penting sebagai warisan sejarah dan budaya bangsa Indonesia. Studi ini bertujuan untuk ikut berpastisipasi mengabadikan benda-benda peninggalan prassejarah tersebut dalam karya seni fotografi bergenre "story". Genre fotografi story adalah genre yang memfokuskan pada visualisasi sisi humanis untuk menghadirkan interaksi manusia dengan lingkungan alam sekitarnya. Dengan menggunakan metode kombinasi, studi ini menggunakan pendekatan semiotika komunikasi visual yang menekankan pada pembacaan dan pemahaman terhadap tanda-tanda visual di dalam teknik fotografi, khususnya pada unsur fokus dan ruang tajam di dalam teknik pengambilan gambar. Hasil survey secara kuantitatif dalam studi ini menunjukkan masih rendahnya pandangan tentang daya tarik kehidupan manusia di area situs prasejarah yang dapat dijadikan objek fotografi. Sedangkan analisis hasil data secara kualitatif dari karya foto dalam studi ini mampu merepresentasikan adanya interaksi manusia dengan alam dan lingkungannya, sehingga membangun persepsi visual tentang manusia sebagai makhluk sosial budaya. Keberadaan situs prasejarah dalam karya fotografi ini juga menghasilkan visualisasi perilaku menusia yang mencoba merasakan kedekatannya dengan peradaban di masa lalu. Studi tentang genre fotografi story dalam latar prasejarah ini menunjukkan bahwa karya fotografi dapat membawa pesan budaya. Penelitian ini juga dapat dimanfaatkan sebagai referensi dalam memenuhi tuntutan perkembangan teknologi yang semakin kompetitif di bidang fotografi maupun desain komunikasi visual.
\end{abstract}

Kata Kunci: representasi, interaksi manusia, genre fotografi, story, megalitikum

\begin{abstract}
The Gunung Padang Megalithic Site is located in Karyamukti Village, Cianjur Regency. Patterned stones arranged on five terraces have been discovered at the site, dating back to prehistoric times. This site is a valuable historical and cultural heritage of the Indonesian people. This study aims to participate in preserving historical relics through "story" genre photography. Story photography genre focuses on visualizing the humanistic side to present human interaction with surrounding natural environment. Through combination method, this study uses semiotic approach to visual communication that emphasizes reading and understanding of visual signs in photographic techniques, especially on the elements of focus and depth of field in photography techniques. Quantitative survey result in this study shows a shallow understanding of the appeal of human life in prehistoric sites as photographic objects. Meanwhile, the qualitative analysis of the data from the photographs in this study can represent the existence of human interaction with nature and the environment, thus building a visual perception of humans as social and cultural beings. The existence of prehistoric sites in this photographic work also results in visualization of human behavior that attempts to feel its closeness to ancient civilization. The study of the story genre photography in prehistoric setting shows that photography can carry cultural messages. This research can also be used as a reference in meeting the demands of increasingly competitive technological developments in the field of photography and visual communication design.
\end{abstract}

Keywords: representation, human interaction, photography genre, story, megalithic 


\section{PENDAHULUAN}

\section{Latar Belakang}

Situs Gunung Padang merupakan wilayah di Kabupaten Cianjur, tempat ditemukannya buktibukti arkeologis dari zaman prasejarah, Megalitikum. Situs ini dibagi ke dalam lima wilayah jangkauan, yaitu gerbang masuknya yang terletak di Desa Karyamukti, kemudian jalur pendakian yang terdiri dari dua cabang, wilayah teras bebatuan berundak yang terdiri dari lima teras, dan bagian terakhir adalah puncak Gunung Padang. Hasil catatan jurnalistik Hermawan Aksan (2015) menjelaskan bahwa Gunung Padang hanyalah sejenis bukit yang berbentuk kerucut, tinggi dan besar. Gunung ini terkadang mengeluarkan lahar dan asap. Puncak Gunung Padang berada diketinggian 989 meter di atas permukaan laut.

Bukti-bukti arkeologis Megalitikum pada situs ini telah mendorong Tim Katastropik Purba pada tahun 2011 untuk melakukan penelitian. Tim ini diinisiasi oleh Andi Arief, Staf Khusus Presiden bidang bantuan sosial dan bencana, dengan tujuan meneliti lokasi-lokasi bencana besar di masa lalu, untuk mengantisipasi kemungkinan terulangnya bencana yang sama (Akbar, 2014). Sejak itulah, kawasan Situs Gunung Padang tidak hanya menjadi sasaran penelitian, melainkan juga destinasi wisata. Berdasarkan hasil wawancara tim peneliti dengan Kang Nanang, Koordinator Juru Pelihara Situs Gunung Padang, setiap harinya situs ini dikunjungi oleh ratusan wisatawan, bahkan di hari libur bisa mencapai ribuan wisatawan, baik lokal maupun mancanegara.

Penelitian tentang simbol-simbol perupaan yang terdapat pada situs Megalitikum terbesar di Asia Tenggara ini pernah dilakukan dan mengasumsikan bahwa situs ini pernah menjadi tempat pemujaan dari masyarakat kebudayaan megalitik yang menganut animisme. Hal ini terlihat dari adanya simbol-simbol kepercayaan Sunda Wiwitan yang dibangun secara estetis dan bernilai budaya tinggi pada konstruksi situsnya. Situs ini sendiri memiliki luas 3132,15 meter persegi (Ramadina, 2013).

Penelitian lain yang terkait lingkungan sosial budaya masyarakat di area situs tersebut pernah pula dilakukan oleh Lutfi Yondri (2014), dari Fakultas Ilmu Budaya, Universitas Padjadjaran Bandung. Penelitiannya membahas tentang fisik dan struktur balok-balok batu yang membentuk punden berundak sebagai refleksi adaptasi kondisi lingkungan dari masyarakatnya.

Gambaran tentang kehidupan manusia di masa lalu dan interaksinya yang terjadi saat ini merupakan daya tarik penting dalam karya seni fotografi, sebagai upaya untuk menghadirkan nilai-nilai budaya sebagai sebuah kearifan lokal. Sebagaimana dikatakan Matsumoto dan Juang (2013 dalam Hambalie \& Dewi, 2018: 371), nilai budaya termasuk dalam satu unsur elemen subjektif yang menjadi bagian kebudayaan namun tidak bertahan secara fisik sebagai artefak. Nilai budaya lebih bersifat abstrak sebagai ide dan dijadikan pedoman individu dalam bertingkah laku pada masyarakat tertentu.

Peninggalan punden berundak di Situs Gunung Padang juga memiliki nilai budaya karena memberikan gambaran tentang aktivitas dan perilaku manusia prasejarah dalam menghadapi tantangan bencana alam, di mana saat itu belum ada teknologi. Dalam penelitiannya, Yondri (2013: 169) menuliskan pemikiran Ridwan (2010), bahwa ada hubungan timbal balik antara lingkungan dengan tingkah laku. Dalam teori human ecology dikatakan lingkungan dapat mempengaruhi tingkah laku manusia dan sebaliknya. Penelitiannya tentang susunan batu yang membentuk punden berundak diasumsikan sebagai cara-cara manusia pada masa itu untuk beradaptasi dengan lingkungan yang rawan. Wilayah perbukitan Gunung Padang yang curam mengharuskan masyarakat Megalitik bekerja keras dengan teknologi sederhana untuk menyusun 
bebatuan di perbukitan yang terjal agar terhindar dari longsor dan tahan gempa. Pengetahuan mereka yang dapat ditemukan dalam konstruksi sisa bangunan punden berundak dianggap sebagai bentuk kearifan lokal dan menjadi nilai budaya.

Oleh karena itu, sebaran batu di lima teras situs tersebut masih terus diteliti hingga saat ini sebagai sebuah misteri kehidupan manusia di zaman Megalitikum. Tim peneliti pun berupaya menjadi bagian dari misteri kehidupan manusia tersebut dengan cara memvisualisasikan keberadaan batu-batu prasejarah melalui genre fotografi story, di mana sisa batu dengan ragam bentuknya mampu membangun imajinasi tentang peradaban manusia di masa lalu dan kedekatannya dengan manusia saat ini. Genre fotografi story merupakan kreativitas karya foto yang mengedepankan pada representasi kehidupan manusia (human interest) sebagai makhluk sosial budaya di lingkungan alam sekitarnya.

\section{Rumusan Masalah}

Adapun rumusan masalah pada studi ini adalah membahas bagaimana merepresentasikan interaksi manusia melalui unsur visual dalam karya fotografi story tentang Situs Megalitikum Gunung Padang? Studi ini dapat menjadi referensi visual yang informatif sekaligus komunikatif, khususnya kemampuan dalam memahami dan menerapkan bahasa visual melalui genre fotografi story tentang situs prasejarah dan interaksinya dengan manusia dalam perkembangan zaman saat ini. Studi ini juga dapat mendorong para fotografer untuk menghasilkan karya foto yang kompetitif secara nasional maupun internasional.

\section{METODE PENELITIAN}

Metode kombinasi, berupa penggabungan jenis penelitian kuantitatif dan kualitatif digunakan dalam studi ini. Secara kuantitatif, penelitian ini melakukan survei terhadap mahasiswa desain sebagai penelitian pendahuluan untuk mengetahui pandangan atau persepsi mereka terhadap genre fotografi story dan fokus daya tarik kehidupan manusia di area situs prasejarah yang dijadikan sebagai objek penelitian fotografi. Secara kualitatif, data dikumpulkan melalui studi literatur, observasi, dan wawancara untuk dianalisis dengan pendekatan semiotika komunikasi visual dan prinsip-prinsip dasar dalam teori fotografi, terutama dalam dua prinsip berikut:

a. Prinsip diferensiasi dan koneksi

Pada prinsip ini, pengambilan gambar dilakukan dengan menempatkan elemen visual sesuai fungsi dan relasinya sebagai pembawa pesan.

b. Prinsip fokus dan konteks

Prinsip ini untuk menentukan fokus dan ruang tajam, yaitu menetapkan fokus objek visual sesuai konteksnya untuk menemukan interaksi antara manusia dengan lingkungan alamnya.

Unsur-unsur inilah yang dijadikan dasar dalam menghasilkan karya seni fotografi bergenre story. Hasil data kuantitatif menjadi dasar analisis terhadap hasil karya seni fotografi dengan genre story. 


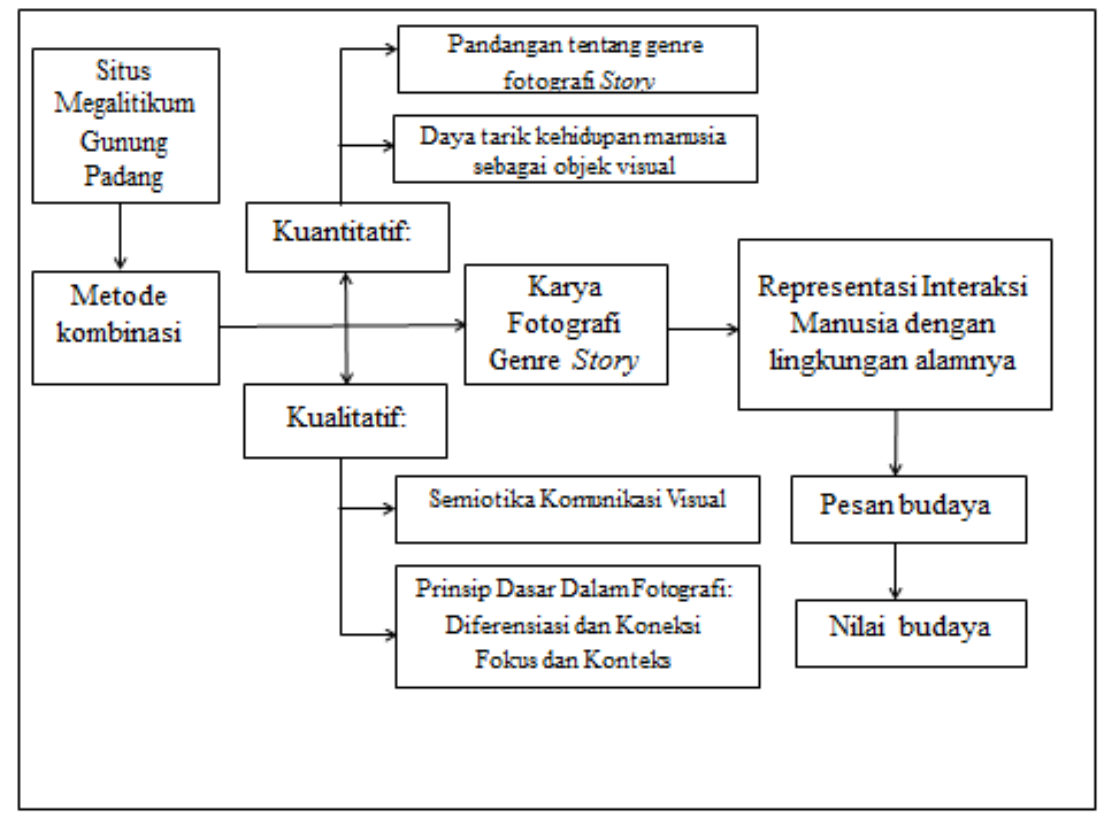

Gambar 1. Bagan Metode Analisis

\section{TINJAUAN LITERATUR}

\section{Semiotika Komunikasi Visual}

Mengkomunikasikan pesan di dalam karya foto berarti membaca dan mengolah struktur tanda berupa elemen-elemen visual yang membentuk objek. Semiotika atau ilmu tentang tanda banyak digunakan di dalam bidang desain komunikasi visual, sehingga pendekatan semiotika komunikasi visual sering digunakan untuk menganalisis berbagai objek desain, termasuk karyakarya di dalam buku foto.

Di dalam fenomena kebudayaan, cakupan tanda sangat luas. Akan tetapi, selama unsur-unsur kebudayaan mengandung makna, maka ia dapat menjadi objek kajian semiotik. Untuk menganalisis foto dapat melihat bermacam tanda yang digunakan, bagaimana tanda menimbulkan arti, bagaimana tanda berhubungan, dan apa yang dipancarkan tanda tentang masyarakat dan kebudayaannya, serta masalah-masalah yang ditunjukkannya (Berger, 2010).

Untuk membaca dan mengolah karya seni foto tentang kehidupan manusia dan interaksinya di area Situs Megalitikum Gunung Padang, pendekatan semiotika dijadikan sebagai pisau analisis, di mana tanda-tanda visual dapat dipahami dengan teknik melihat sebagai bacaan (Schirato\& Webb, 2004).

\section{Genre Fotografi Story}

Ada banyak genre di dalam fotografi. Namun di dalam penelitian ini, difokuskan pada genre fotografi story (story photography). Dasar pemilihan genre ini membantu memberikan identitas pada karya seni fotografi. Menurut Wilsen Way (2014), genre fotografi story menampilkan visualisasi yang lebih menekankan pada human interest. Jenis fotografi ini dapat menghadirkan emosi tertentu, karena terkait pengalaman personal sang fotografer saat mengabadikan "story". Genre fotografi yang menekankan sisi humanis lebih banyak menghadirkan interaksi manusia dengan lingkungan alam sekitarnya, yang pemotretannya dilakukan secara sembunyi-sembunyi (candid) dan sesuai aktivitas alami yang sedang dilakukan. Pemotretan juga dilakukan dengan 
kecenderungan mengabadikan reaksi, ekspresi, dan perilaku spontan dari manusianya, dengan latar lingkungan sekitarnya yang mendukung pesan yang ingin disampaikan.

Oleh karena itu, dalam genre story, hasil karya foto dapat saja menggugah rasa bagi yang melihatnya. Foto story dapat menyampaikan pesan foto yang kuat, mampu membangkitkan semangat, dan perasaan lain, seperti menghibur, perasaan haru, bahkan memancing perdebatan (Hidayat dan Arumsari, 2017). Dalam studi ini, pilihan jenis foto story yang digunakan adalah bersifat naratif, yaitu bertutur dari satu kondisi ke kondisi lainnya yang tidak terkait secara kronologis, namun lebih mengutamakan keterkaitan dengan benda-benda di sekeliling dan area latarnya.

\section{HASIL DAN PEMBAHASAN}

Studi ini melakukan survei dengan menggunakan kuesioner tertutup terhadap 175 mahasiswa desain di lingkungan Universitas Indraprasta PGRI Jakarta untuk mengetahui pendapat mereka tentang penggunaan genre fotografi story pada karya seni fotografi tentang situs prasejarah. Hasil data survei yang dianalisis menggunaka skala Guttman menunjukkan 137 (78\%) mahasiswa menganggap genre fotografi story diperlukan, sedangkan sebanyak 13 (8\%) mahasiswa menyatakan tidak, dan 25 (14\%) mahasiswa menyatakan tidak tahu. Hasil data menunjukkan tingginya pandangan tentang daya tarik genre fotografi story.

Sedangkan hasil data survey untuk mengetahui pendapat mahasiswa desain tentang daya tarik kehidupan masyarakat di area situs prasejarah sebagai objek fotografi menunjukkan hasil yang menarik. Sebanyak 50 (29\%) mahasiswa menganggap kehidupan masyarakat dapat menjadi daya tarik objek foto, sedangkan sebanyak 26 (15\%) mahasiswa menyatakan tidak, dan 99 (56\%) mahasiswa menyatakan tidak tahu. Hasil ini menunjukkan bahwa masih rendahnya sensitivitas terhadap objek foto yang mengangkat tentang kehidupan manusia di area situs prasejarah.

Hasil data kuantitatif tentang genre ini menjadi dasar untuk menganalisis kekuatan visual di dalam genre fotografi story. Hasil data ini juga menjadi dasar pembahasan tentang daya tarik visual dari kehidupan masyarakat dan interaksinya dengan alam yang dapat dijadikan karya seni foto, terutama untuk menyampaikan pesan tentang nilai-nilai sejarah dan budaya, yang dihadirkan sebagai konteks latar. Berikut hasil data yang digambarkan melalui grafik. 


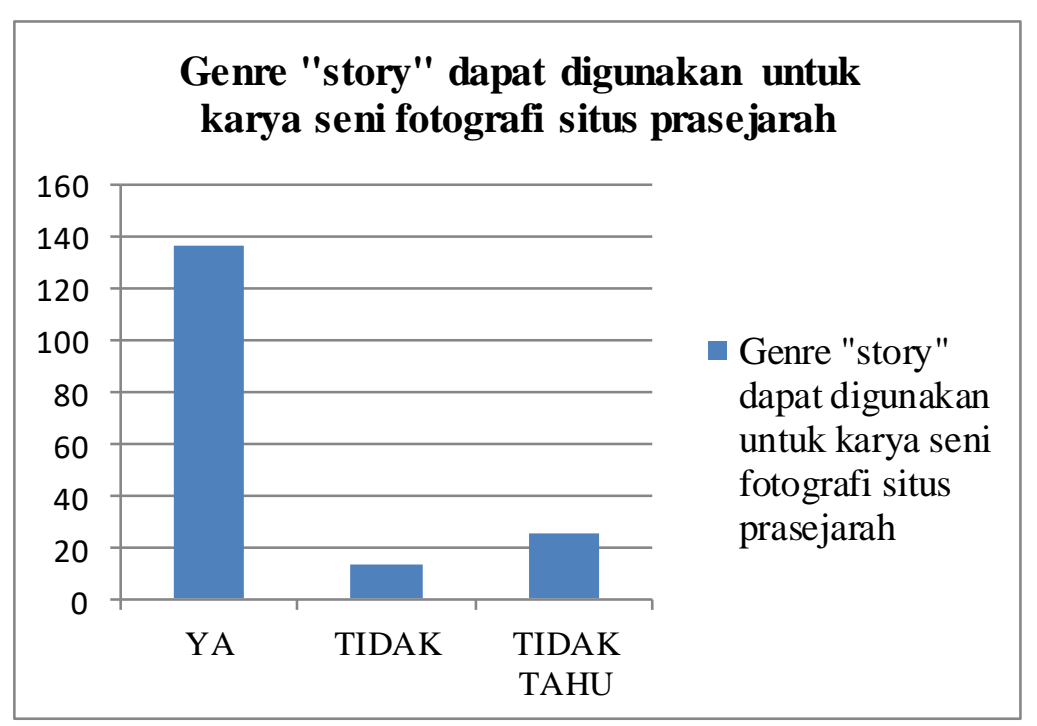

Gambar 2. Pandangan Tentang Genre Story Untuk Karya Seni Fotografi Situs Prasejarah Sumber gambar: Dokumentasi Tim Peneliti

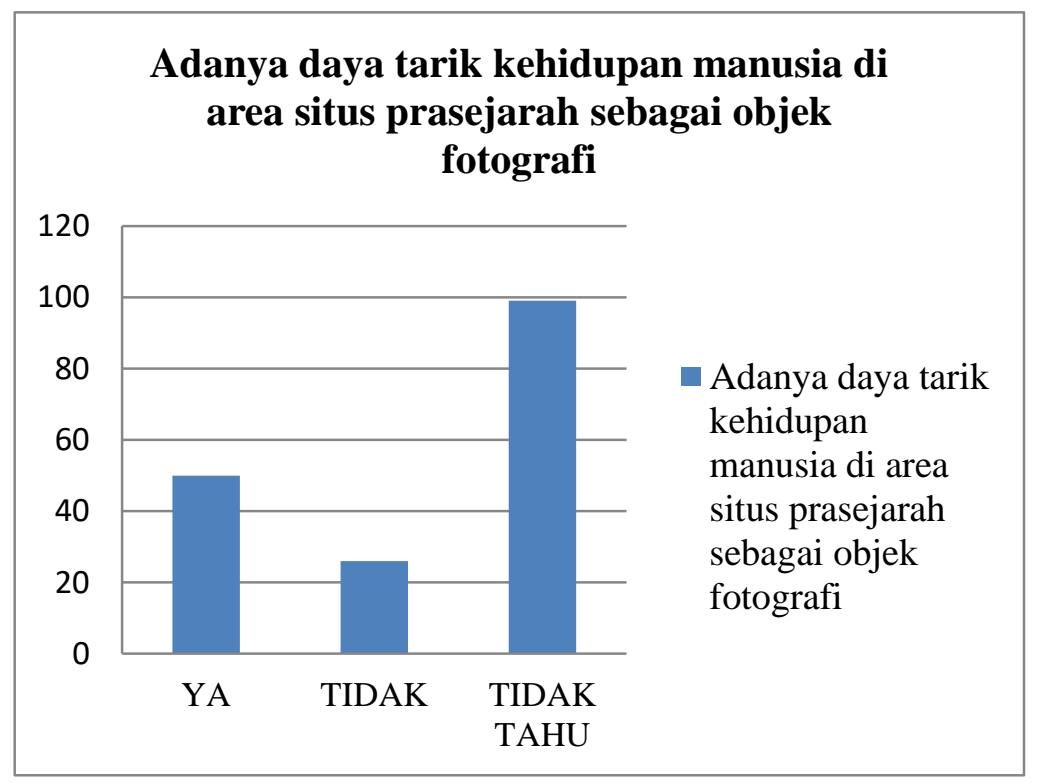

Gambar 3. Pandangan Tentang Daya Tarik Kehidupan Manusia di Area Situs Prasejarah Sumber gambar: Dokumentasi Tim Peneliti

\section{Representasi Interaksi Manusia}

Untuk merepresentasikan interaksi manusia dengan lingkungan alamnya, pemotretan dilakukan secara candid terhadap aktivitas masyarakat yang ada di area situs. Representasi merupakan keadaan yang dihadirkan untuk diwakili. Pemikiran Schroeder dan Borgerson (2005), serta Branston dan Stafford (2006) merumuskan representasi sebagai keadaan yang dapat terkait di dalam produksi makna dan disampaikan secara visual melalui sistem tanda bahasa (Wardani, 2011). 
Di dalam prinsip tanda fotografi, studi ini melakukan tahap diferensiasi dan koneksi terlebih dulu, yaitu memilih area sebaran batu sesuai fungsi teras yang dapat leluasa dimasuki oleh masyarakat dan dijadikan tempat duduk, ataupun diinjak. Dari kelima teras berundak yang ada (teras 1 hingga teras 5), hampir seluruhnya dapat dimasuki, dan hanya sebaran batu-batu tertentu saja yang diberikan petunjuk larangan untuk dimasuki. Hal ini memungkinkan untuk menjadikan setiap wilayah teras di situs tersebut sebagai fokus dan ruang tajam objek yang berelasi langsung dengan wujud batu sebagai konteks latar sejarah.

Tahap memilih objek yang dijadikan fokus di dalam ruang tajam dibagi menurut lima aktivitas interaksi manusia, yaitu interaksi manusia dalam aktivitas kasih sayang, interaksi manusia dalam aktivitas kekeluargaan, interaksi manusia dalam aktivitas persahabatan, interaksi manusia dalam aktivitas aktualisasi diri, serta interaksi manusia dalam aktivitas menjaga kebersihan alam. Pilihan objek aktivitas interaksi manusia ini didasarkan pada dinamika dan aktivitas masyarakat yang umumnya dilakukan di area situs prasejarah tersebut.

Prinsip fokus di dalam teknik fotografi akan membantu pembaca untuk memahami pesan yang disampaikan. Fokus berarti menempatkan objek foto di dalam komposisi sebagai pokok pembahasan karya foto. Objek foto sebagai fokus adalah konten dari pesan foto yang dihadirkan di dalam ruang tajam. Artinya, objek foto harus terlihat jelas, menarik perhatian, terlihat ekspresif, dan mengarahkan pandangan mata secara visual. Berikut visualisasi dari representasi interaksi manusia dengan aktivitasnya di area Situs Megalitikum Gunung Padang.

\section{a. Representasi Interaksi Manusia dalam Aktivitas Kasih Sayang}

Representasi interaksi manusia dalam aktivitas kasih sayang divisualisasikan melalui objek foto sepasang kekasih sebagai fokus di antara sebaran batu-batu prasejarah yang diabadikan dalam latar bebatuan di atas bukit. Interaksi manusia dalam genre story ini menarasikan bahwa alam dalam sejarah peradabannya adalah saksi bisu atas hubungan kasih sayang manusia.

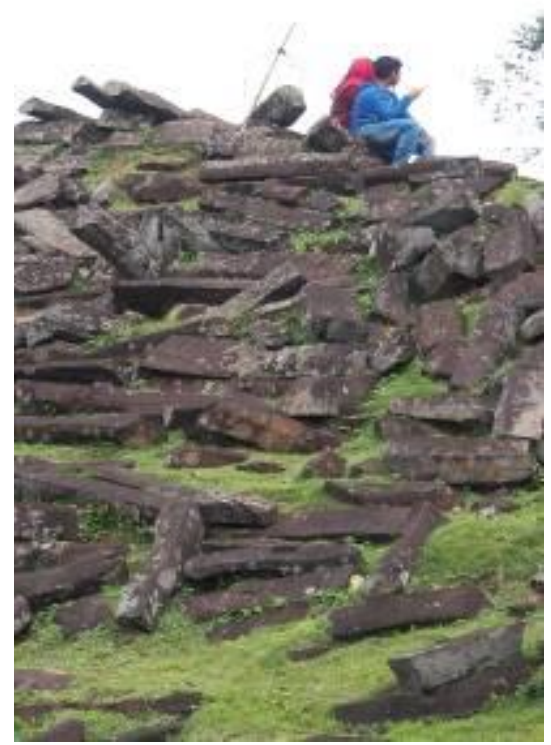

Gambar 4. Representasi Interaksi Manusia dalam Aktivitas Kasih Sayang Sumber gambar: Dokumentasi Tim Peneliti 


\section{b. Representasi Interaksi Manusia dalam Aktivitas Kekeluargaan}

Representasi interaksi manusia dalam aktivitas kekeluargaan divisualisasikan melalui objek foto yang menampilkan seorang petugas Gunung Padang (berpakaian hitam) tengah duduk berbincang dengan penduduk lokal di antara bebatuan yang berbentuk vertikal, sambil menikmati minuman. Objek foto menjadi fokus pembahasan dan membawa pesan tentang terjalinnya komunikasi yang penuh keakraban di area situs tersebut. Area situs prasejarah menjadi narasi ruang yang hangat untuk menjalin persaudaraan dan keharmonisan.

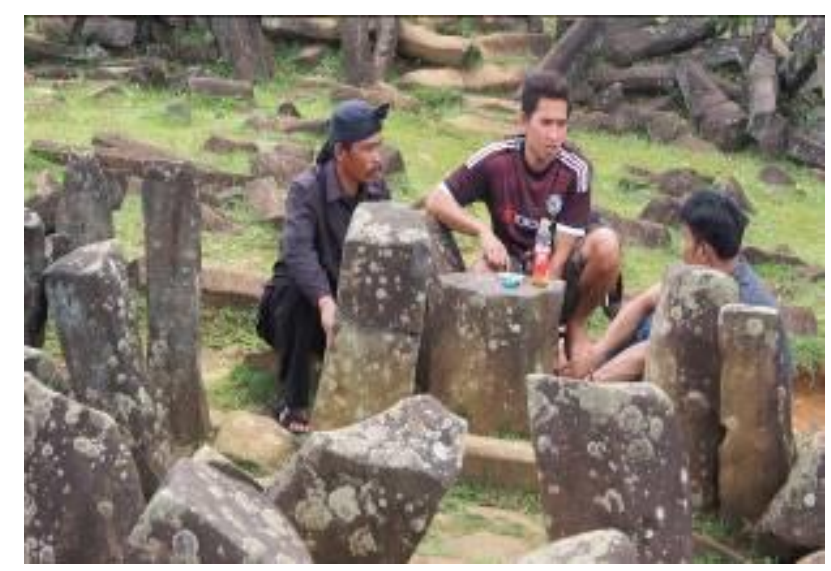

Gambar 5. Representasi Interaksi Manusia dalam Aktivitas Kekeluargaan Sumber gambar: Dokumentasi Tim Peneliti

\section{c. Representasi Interaksi Manusia dalam Aktivitas Persahabatan}

Representasi interaksi manusia dalam aktivitas persahabatan divisualisasikan melalui objek foto dua orang pemuda sebagai fokus di antara struktur berpola batu-batu prasejarah yang letaknya saling menyilang dan bertumpuk. Kedua pemuda divisualisasikan sedang duduk berdampingan dan berdekatan di antara bebatuan dalam suasana yang nyaman, sehingga terlihat asyik menikmati ruang dan waktu di sekitarnya. Aktivitas kedua pemuda dalam genre story ini menarasikan makna secara visual tentang hubungan emosi dan makna persahabatan. Wujud batu yang beragam sebagai latar dapat merefleksikan sifat-sifat di dalam persahaatan manusia yang tak lekang oleh waktu.

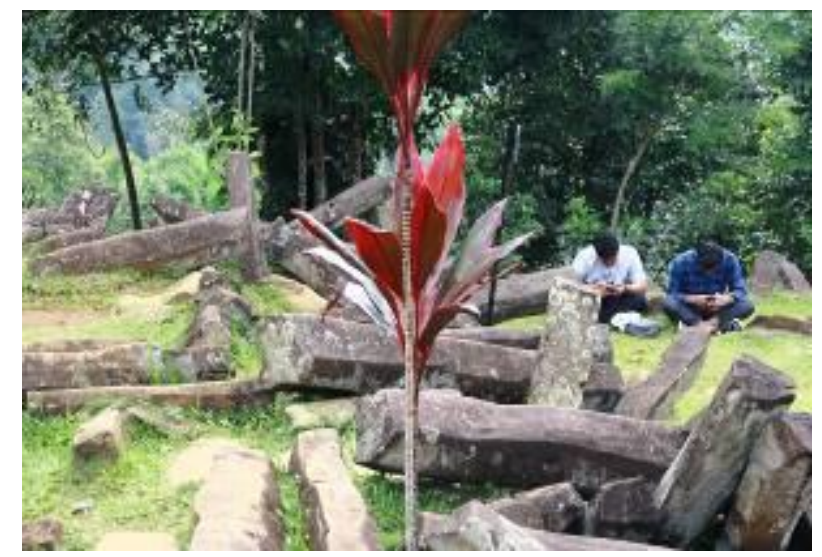

Gambar 6. Representasi Interaksi Manusia dalam Aktivitas Persahabatan

Sumber gambar: Dokumentasi Tim Peneliti 


\section{d. Representasi Interaksi Manusia dalam Aktivitas Aktualisasi Diri}

Representasi interaksi manusia dalam aktivitas aktualisasi diri divisualisasikan melalui objek foto remaja perempuan yang asyik berswa foto sebagai fokus di antara sebaran batu-batu prasejarah. Interaksi manusia ini menarasikan bahwa kebutuhan akan eksistensi diri manusia adalah bagian dari peradaban manusia, di mana tanpa adanya aktualisasi diri maka kehidupan manusia itu sendiri tidak akan melahirkan kemajuan. Aktivitas aktualisasi diri dalam genre story ini adalah refleksi dari karakter manusia yang selalu ingin hadir di alam semesta, sebagai makhluk sosial yang ingin terlibat dan berperan di dalam lingkungannya.

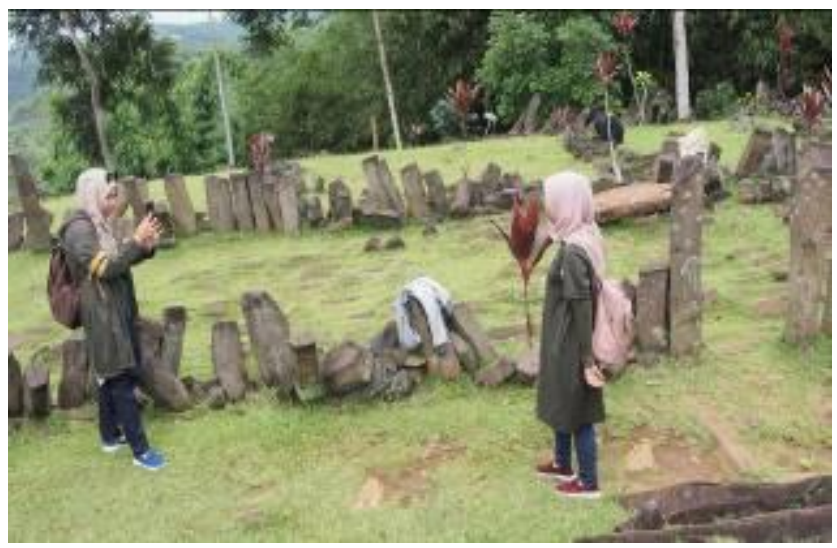

Gambar 7. Representasi Interaksi Manusia dalam Aktivitas Aktualisasi Diri

Sumber gambar: Dokumentasi Tim Peneliti

\section{e. Representasi Interaksi Manusia dalam Aktivitas Menjaga Kebersihan Alam}

Representasi interaksi manusia dalam aktivitas menjaga kebersihan alam divisualisasikan melalui objek foto seorang petugas kebersihan Gunung Padang yang sedang bekerja membersihkan sampah di antara bebatuan sebagai fokus di dalam ruang tajam.

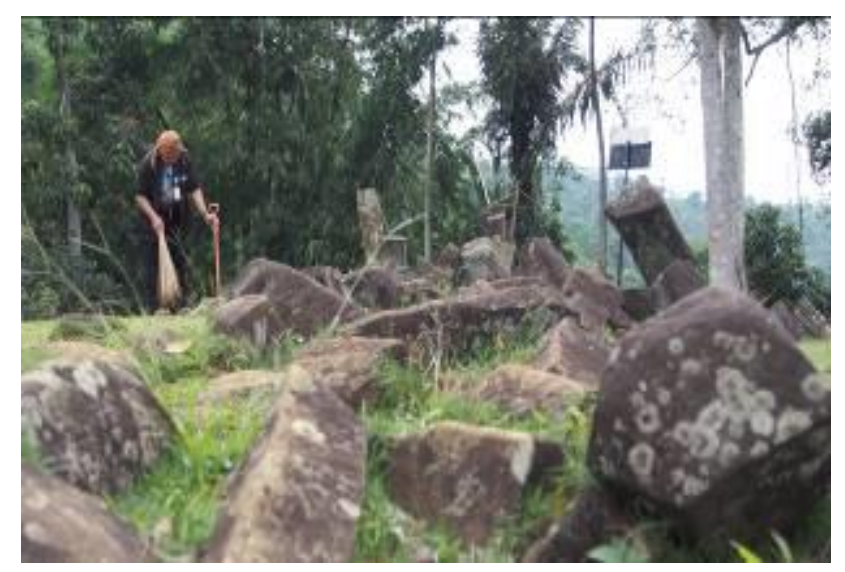

Gambar 8. Representasi Interaksi Manusia dalam Aktivitas Menjaga Kebersihan Alam Sumber gambar: Dokumentasi Tim Peneliti

Aktivitas manusia ini menarasikan tentang besarnya tanggung jawab petugas kebersihan, sebagai pengelola sekaligus penjaga area situs dari kerusakan-kerusakan yang disebabkan oleh manusia maupun alam itu sendiri. Sampah-sampah yang umumnya berserakan di antara bebatuan dapat berupa kotoran yang secara sengaja dibuang oleh pengunjung yang tidak bertanggungjawab, juga 
dedaunan kering yang berguguran dari pepohonan besar di sekitarnya. Dalam genre story, visualisasi dalam foto berupa objek foto sosok yang sedang menyapu adalah seuah narasi tentang kewajiban semua manusia untuk bersama-sama menjaga alamnya dari potensi-potensi yang merusak. Pesan dalam foto ini berupaya mendorong kesadaran manusia untuk menjaga penginggalan sejarah di lingkungan alamnya.

Demikian kelima representasi interaksi manusia dalam interaksinya dengan lingkungan alam di area situs prasejarah yang dapat divisualisasikan melalui genre fotografi story. Kelima representasi tersebut adalah sebuah narasi tentang kehidupan manusia dengan sisi-sisi humanisnya sebagai makhluk sosial dan budaya.

\section{KESIMPULAN DAN SARAN}

Hasil studi menunjukkan penggunaan genre fotografi story dalam karya seni tentang situs prasejarah, khususnya Situs Megalitikum Gunung Padang dapat menghadirkan sisi kehidupan manusia dalam interaksinya dengan alam. Selain itu, genre fotografi story juga menjadi daya tarik dalam merepresentasikan interaksi dan kehidupan manusia sebagai makhluk sosial budaya, yang terkait dengan masa lalu dan masa kini. Pembacaan dan pengolahan elemen-elemen visual di dalam prinsip tanda fotografi memiliki potensi untuk dikembangkan melalui tahapan diferensiasi dan koneksi, fokus dan konteks dalam penerapan unsur fokus dan ruang tajam. Hasil foto genre story dalam studi ini mampu menunjukkan representasi interaksi manusia di dalam aktivitas kasih sayang dengan sesamanya, kebersamaan bersama keluarga, aktivitas persahabatan, aktivitas aktualisasi diri, dan aktivitas menjaga kebersihan alam. Objek foto sebagai bagian dari unsur visual yang dilatari sebaran batu-batu prasejarah, mampu menghadirkan fungsi dan relasinya untuk membawa pesan tentang peradaban dan perkembangannya saat ini. Dengan tetap mempertimbangkan komposisi, bentuk, dan pencahayaan, sebagai kekuatan visual yang mendukung karya seni fotografi, hasil studi ini dapat menjadi referensi bagi pembaca untuk ikut menikmati dan menghargai Situs Megalitikum Gunung Padang sebagai warisan sejarah dan budaya dengan cara-cara yang lebih humanis.

Studi tentang genre fotografi story berlatar prasejarah ini diharapkan dapat menginspirasi penciptaan karya-karya seni foto lainnya. Karya fotografi juga termasuk di dalam industri kreatif yang memiliki daya saing global, sehingga diperlukan kreativitas para kreator di bidang desain komunikasi visual untuk terus meningkatkan pengetahuan dan wawasan tentang genre fotografi guna menghasilkan karya-karya yang kompetitif di mancanegara, tentunya dengan tetap mengedepankan latar budaya Indonesia. Sebaiknya para praktisi fotografer juga dapat memanfaatkan kekayaan budaya Indonesia sebagai objek fotografi yang mampu menggugah insiprasi dan memperkaya wawasan sejarah bangsa melalui kekuatan visual foto yang menarik.

\section{Ucapan Terima Kasih}

Apresiasi dan terima kasih kepada Direktorat Riset dan Pengabdian Masyarakat, Dirjen Penguatan Riset dan Pengembangan, Kementerian Riset, Teknologi dan Pendidikan Tinggi dan yang telah membiayai kegiatan Penelitian Dasar Unggulan Perguruan Tinggi (PDUPT) Tahun 2019 dengan judul: "Perancangan buku foto situs Megalitikum Gunung Padang dengan genre still life, landscape, dan story sebagai upaya melestarikan warisan sejarah dan budaya di Desa Karyamukti Cianjur". Terima kasih juga kepada LLDIKTI Wilayah III Jakarta dan Lembaga Penelitian dan Pengabdian Masyarakat Universitas Indraprasta PGRI yang telah membantu kegiatan penelitian ini melalui Kontrak Penelitian: Nomor: 16/AKM/PNT/2019, Tanggal 27 Maret 2019. 


\section{REFERENSI}

Akbar, A. (2014). Situs Gunung Padang, Misteri dan Arkeologi. Change Publication, Jakarta.

Aksan, H. (2015). Gunung Padang, Penelitian Situs dan Temuan Menakjubkan. Penerbit Nuansa Cendekia, Bandung.

Berger, A. A. (2010). Pengantar Semiotika, Tanda-tanda Dalam Kebudayaan Kontemporer. Tiara Wacana, Yogyakarta.

Hambalie, H.C. \& Dewi, F. I.R. (2018). Gambaran Nilai Budaya Antara Generasi Tua dan Generasi Muda Pada Masyarakat Tionghoa Beragama Konghucu. Jurnal Muara Ilmu Sosial, Humaniora, dan Seni, 2 (1)369-377

Hidayat, M. F., dan Arumsari, R. Y. (2017). "Perancangan Buku Photo Story". e-Proceeding of Art \& Design, 4 (3), 596-603.

Ramadina, S. P. (2013). “Analisis Perupaan Situs Megalitik Gunung Padang di Cianjur, Jawa Barat". Fakultas Seni Rupa dan Desain. Institut Teknologi Bandung. J. Vis. Art \& Des, 4 (1), 51-66.

Schirato, T. \& Webb, J. (2004). Reading the Visual. Alen \& Unwin, Crows-Nest.

Wardani, W. G. W. (2011). "Representasi Manusia Sebagai Makhluk Budaya Dalam Film Animasi Jepang Nonverbal 'La Maison En Petits Cubes"”. Tesis. Universitas Trisakti, Jakarta.

Way, W. (2014). Human Interest Photography, Mengungkap Sisi Kehidupan Secara Langsung dan Jujur. PT. Elex Media Komputindo, Jakarta.

Yondri, L. (2013). Konstruksi dan Pola Susun Balok Batu Punden Berundak Gunung PadangCianjur. Purbawidya, 2 (2), 163-181.

Yondri, L. (2014). Punden Berundak Gunung Padang "Refleksi Adaftasi Lingkungan dari Masyarakat Megalitik". Fakultas Ilmu Budaya. Universitas Padjadjaran Bandung. Jurnal Sosioteknologi, 13 (1), 1-14. 